\title{
AN ANALYSIS OF AIRLINES CUSTOMER SATISFACTION BY IMPROVING CUSTOMER SERVICE PERFORMANCE
}

\author{
Kevin Tegar B.S ${ }^{1}$, Anggun Lestari ${ }^{2}$, Sekar Widyastuti Pratiwi ${ }^{3}$ \\ 1. STMT Trisakti 2. STMT Trisakti 3. STMT Trisakti \\ $\triangle$ corresponding author: anggunlestarianggun@gmail.com
}

\begin{abstract}
Airlines industry is currently the biggest industry of transportation in the world. It focuses in service strategy to get costumers, because a great quality of service is a way to get customer loyalty. The objectives of this study are to examine and to identify the ways to increase airline customer satisfaction with service quality dimension, consisting of tangibility, reliability, responsiveness, assurance, and empathy. The research mode is descriptive quantitative. This study uses customer service theory and random sampling technique by providing a form of questions with 150 respondents as samples. The data collected were analysed with Cartesius diagram. This chart can be used to identify services and the customer satisfaction towards the quality of services of the company. The main purpose of this research is to achieve customer satisfaction in order to get loyalty from airline customers by improving the service quality dimensions, especially in Responsiveness, Reliability and Empathy.

Keywords: Customer Satisfaction, Customer Service, Airlines, Service Quality Dimensions.
\end{abstract}

\section{Introduction}

Transportation services have become the basic needs of the community both for daily activities and travel needs. For a long-distance journey, most people prefer air transportation for the efficiency and effectiveness of time. Air transport can reach places that cannot be reached by other modes of transport such as land and sea, in addition to being able to move faster and have a straight, practically barrier-free path (Setiani, 2015). With the enactment of the ASEAN Single Aviation Market (ASEAN-SAM), a major regional aviation policy aimed at establishing a single and integrated aviation market in Southeast Asia by 2015 and designed to realize full liberalization of air travel between ASEAN member countries, a strict competition among airlines ensues. Indonesia is not an exception, all airlines are competing to improve the superior quality of service to meet customer satisfaction. 
This fact is coupled with the issuance of Indonesian Minister of Transportation Decree No. 81 of 2004 on the Establishment of Airline Companies in Indonesia. The large number of airlines operating in Indonesia increases the competitiveness among airlines. Indonesia currently has 22 airlines under OC (operator certificate) 121 and 35 airlines under AOC (Air Operator Certificate) 135 airlines serve around 400 domestic and international route flights and connects 121 cities in Indonesia and 21 countries in the world. The number of domestic air transport passengers grew an average of 13.8 percent per year between 2009- 2013 and the number of passengers for international flights grew 19.3 percent during the same period. Meanwhile, global air transport grew 5 percent per year or doubled every 15 years and air travel in Indonesia doubled every 10 years (Directorate General of Air Transportation, 2014). Aviation practitioners should ensure that the quality 'of service provided can have an impact on customer satisfaction.

Satisfaction is not only considered as a customer's goal to be derived as a result of degrading services, but also as a company's goal, as a way of getting higher customer retention rates and ways of generating profits (Surapranata \& Iskandar, 2013). If the service / product provided in accordance with customer expectations, he will feel satisfied that increase the level of consumer loyalty. Conversely, if service delivery is lower than customer expectation, service quality will be considered bad and decrease of constumer loyalty (Saribanon et al., 2016), (Simarmata \& Keke, 2017). According Lupiyodi, Hamdani \& Saribanon, that one way to increase customer loyalty is to improve the quality of service. Customer loyalty is considered as commitment or costumer principle to always choose the service / product is continuous and consistent in the future (Tinggi, Transportasi, Prasetya, Tinggi, \& Transportasi, n.d.)

In theory, if a customer is satisfied with the service or product provided, he will be loyal to use the product and even tells others the benefits of the product or service (Warnock-Smith \& Morrell, 2008). Satisfied customers will continue to buy the product again (Surapranata \& 
Iskandar, 2013). Although customer satisfaction is not the main goal, customer satisfaction is the key to the success of a company to maintain the quality of product / service and maintain the image of the company's brand so that customers will repurchase. That is why, the company must provide superior service quality to win the business competition among Airlines (Setyowati, 2015)

This study aims to examine and analyse the impact of service quality dimensions consisting of tangibility, reliability, responsiveness, assurance, and empathy in improving the quality of service of Indonesian airlines. It also aims to analyse which quality dimensions dominantly affect the service quality in Indonesian airlines. The main purpose of this study is to know and analyse to what extend the suitability between the level of importance of the elements of service according to the customer / passengers and what has been done by the airline Indonesia is considered satisfactory and to find out and analyse the elements of dimensions that need to be improved in order to improve customer satisfaction impact on customer loyalty. The results of the research conducted by Parasuraman et al. (1982), Fuwaheer (2004), Bernadine (2005), Purba (2005), (Koi, 2014), (Pabedinskaitė \& Akstinaitè, 2014), Noor Syamsudin (2015), (Hussain, Al Nasser, \& Hussain, 2015) indicate that service quality dimensions consisting tangibility, reliability, responsiveness, assurance, and empathy have a positive and significant impact on customer satisfaction. (Hussain, Al Nasser, \& Hussain, 2015)

Understanding the quality of service is centred on the fulfilment of customer wants and needs and on delivering them to meet customer expectations in a product/service (Service \& Services, 2011). Quality service is a condition where the fulfilment of willingness and customer expectations of a product/service are achieved (Evan and Lindsay, 2000). Thus, the definition of service quality can be expressed as an effort of a company in providing products/services to customers who can meet or even exceed their expectations. Customer satisfaction is a condition where the realization of the desired expectations of consumers of the services is 
provided (Hapsari, Clemes, \& Dean, 2016). The realization of satisfaction needs, wishes and expectations of customers will impact on customer loyalty (Band, 2010).

\section{Method}

This paper aim to elaborate and analyse ways to improve customer quality and satisfaction including tangibility, reliability, responsiveness, assurance, and empathy in airlines that have impact on passengers satisfaction. Quantitative descriptive is matched with this paper objective and we use Cartesius diagram as the tools. From Cartesius data, we evaluated which dimension of services quality that are lack and try to improve it based our observation. We identified that $\mathrm{X}$ variable is customer services performances and $\mathrm{Y}$ variable is customer satisfaction. This research explained how $\mathrm{X}$ variable impacts $\mathrm{Y}$ variable. The population for this paper is passengers who have used airline services and the samples are some airlines passengers. We collected 150 respondents consists of 79 women (53\%) and 70 men (47\%). The majority of respondents age 15-25 (productive years) years old, or as many as 64 people $(61,7 \%)$.

\section{Discussion and Result}

Service quality can impact customer satisfaction. Service quality is considered as customer's judgment about the entity's overall excellence and superiority. The definition of judgment is more difficult to describe compared to physical product because services are intangible (Parasuraman et al., 1985). According to the scale, there are five dimensions in order to measure service quality. They are tangibility, reliability, responsiveness, assurance, and empathy. At the end we can consider that the quality will be determined as the difference between what the customer expect and what they experience (Parasuraman et al., 1985; Brady and Cronin, 2001). Cronin and Taylor (1994) suggest that the difference between performance and expectations is not an appropriate way to measure service quality. 
In order to improve service quality performance, analysing and evaluating every variables are indeed needed to make greater performance and increasing customer satisfaction. First, reliability is the process of providing services, handling customer services issues and understanding customers. In this process, customer services must provide services which already have been standardized by the company. Customer services also provide service to handle customer problem. In doing this, customer service must be able to do it with simple language which is easy to understand and commonly used. Second, responsiveness is the process to deliver services immediately and fast, the initiative to help and the readiness to find the solution to customer problem. Customer service must be willing to help customer with fast response. They also need to have initiative to offer help to their customers. They must be stand by and find the right solution to different customer problems.

Third, assurance is the process where the ability of the customer service in providing absolute data, their consistency to be polite and their capability to answer customer questions. In giving data, they must give certainty and safe feeling to customer in order to make consumer feel secure. Customer services must tell things truthfully based on reality. If they tell dishonest statement or make it up, there is a chance that the customer will find out. They will feel uncertain and untrusted because the customer service gives false information. So, honesty is an important part in this. Excellence customer services are those who have the skills and are capable to answer and find solution about services that they are offering. Customer will feel pleased with customer service that responsive with their complaint. Polite attitude is also important in providing service to customer because customer tends to respect customer service who have good attitude and behaviour. Fourth, empathy is the process where customer service gives individual attention, treats costumer in an attentive manners, and considers and understand customer needs and interest. In this process, customer services doesn't mind giving individual attention to customers. If customers 
are given attention face to face, the chance for customer to be understood and satisfied is higher than be given attention in group.

Customer treatments also influence their satisfaction about services. When the customer service treats the customer attentively and prioritize their interest they will be satisfied and be loyal.

Understanding customer needs is important in order to know well about their needs, interests and characteristics. So, customer service will treat customer according to their qualification. Fifth, tangibility is the process how they dressed in front of the customers and create suitable workplace. Tangibility is the first impression that customers see before they decide to use the service. Customer service must dress neatly, tidily and appropriately in order to attract customers. Their workplace also must be worth and secure. They need to make comfortable atmosphere which is clean and neat to make customer feel pleasured (Surapranata \& Iskandar, 2013).

Earlier studies found direct relationship between service quality and satisfaction (Cronin and Taylor, 1992; Cronin and Taylor, 1994; Cronin et al., 2000; Keaveney and Parthasarathy, 2001; Lim et al., 2006; Shin and Kim, 2008; Parasuraman, et al, 1988). Cronin et al. (2000) state that favourable service quality perceptions improves satisfaction. According to research by (Darunanto, n.d.) quality of service contributes to customer satisfaction. Satisfaction literature also relates switching intentions and service quality. Studies show that service quality has direct effect on behavioural intentions through satisfaction (Hapsari et al., 2016). According to the studies (Shin and Kim, 2008), when perceived service quality is high, satisfaction will also be high, and then switching tendency of the customers will be low. In addition to direct relationship, Cronin et al. (2000) also propose indirect relationship between service quality and behavioural intentions. They argue that service quality has significant effect on behavioural intentions through satisfaction. Based on our survey data, respondent figures that customer service in airline still doubtful and not satisfying the costumers 


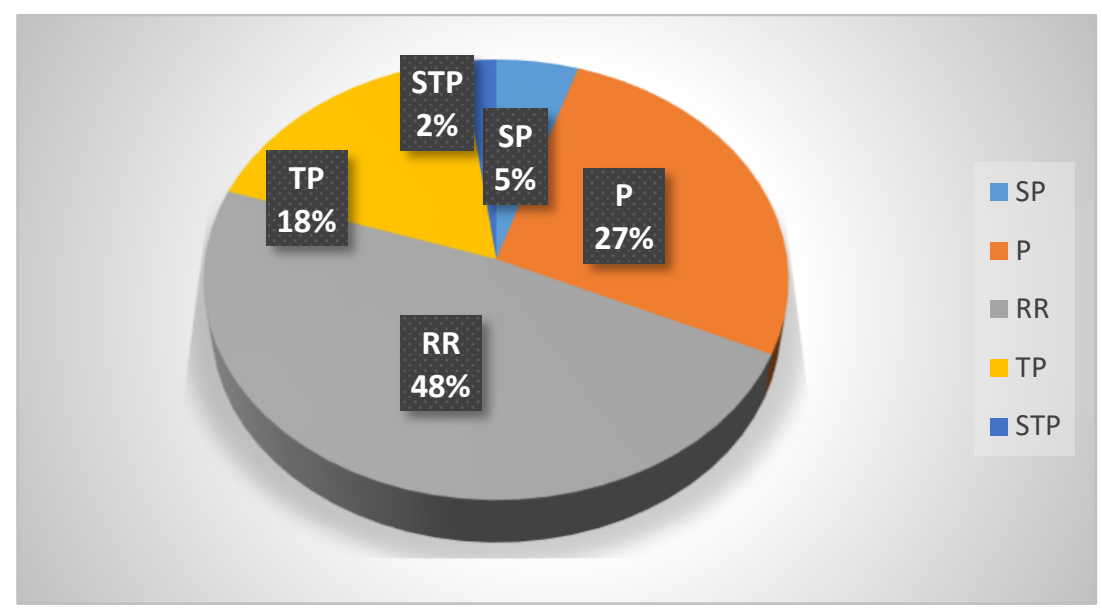

Figure .1

Service Quality Performance

Source : Based on observation

From Figure. 1 we get that the number of passengers who choose $\mathrm{SP}($ Sangat Penting/Very Important) is 119 persons with (5\%), $\mathrm{P}$ (Penting/Important) is 646 persons (27\%), RR (Ragu-Ragu/not sure) is 1159 persons (17\%), TP (Tidak Penting/Not Important) is 426 persons (5\%), and STP (Sangat Tidak Penting/Not Very Important) is 50 person $(2 \%)$.

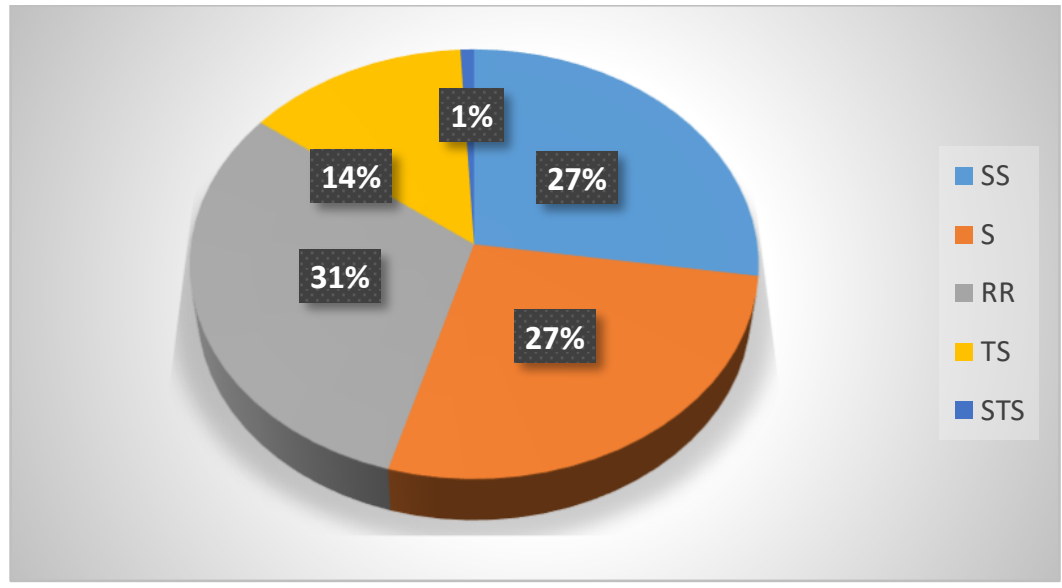

Figure.2

Customer Satisfaction (Y)

Source : Based on observation

From graph.2 we get that the number of passengers who choose SS (Sangat Setuju / Very Agree) is 87 persons (27\%), S (Setuju/Agree) is 863 persons (27\%), RR (Ragu-Ragu / not sure) is 982 persons (31\%), TS (Tidak 
Setuju/Not Agree) is 441 persons (14\%), and STS (Sangat Tidak Setuju/Very Not Agree) is 27 persons (1\%). Overall, based on data in graph 1 and graph 2, service quality performance have good reputation in passengers mind. TKI (compatibility level indicator) shows the result:

$$
\mathrm{Tki}=\frac{x}{y} \times 100 \%=\frac{3,03}{3,25} \mathrm{x} 100 \%=93.2 \%
$$

5 indicators are used to measure customer satisfaction in which unpleased is ranged between (0.00-0. 199), less pleased is ranged between (0.20-0.399), pleased enough is ranged between (0.40-0.599), pleased is ranged between (0.60-0.799) and very pleased is ranged between (0.811.00). TKI points got from this calculation:

$$
\mathrm{Tki}=\frac{\text { performances }}{\text { satisfied }}=\frac{3,03}{3,25}=0,932
$$

Based on TKI indicator, customer already feel very pleased with service quality performance with the result of $93.2 \%$ using scale interpretation measurement by J. Supranto.

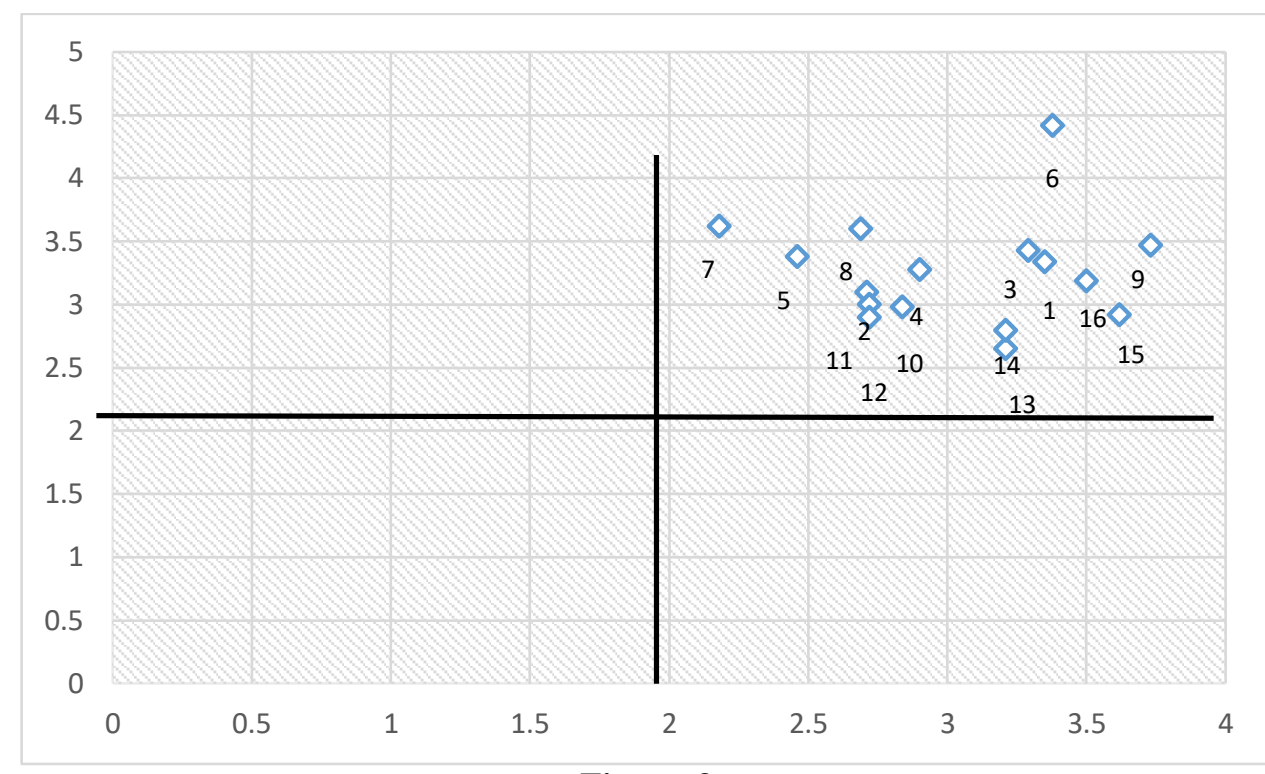

Figure .3

\section{Cartesius Diagram}

Source : Based on our observation

From the graph above, we can describe Quadrant A. is about first priority. There is no factor in this part. Quadrant B. is about keeping position which is not good and not bad for the position. The factors in this quadrant are all based on our observation including quadrant B. Quadrant C. is about the 
lowest position and priority. There is no factor in this part. Quadrant D. is about out of capacity. There is no factor for this part.

\section{Conclusion}

Based on our observation, which includes reliability, responsiveness, assurance, empathy, and tangibility variables, we concluded that these dimensional service qualities influence customer satisfaction in order to increase customer satisfaction. Airlines must pay attention to service quality performances and must optimize their performances. Analysing every dimension of service quality is indeed needed to get for greater results. Cartesius diagram shows that rate of customer satisfaction is at high percentage at $93.2 \%$. The other $7,8 \%$ feel dissatisfied and doubtful. If we take a look on Cartesius diagram, the quality of service performance still in quadran B. which means good but not the first priority. Customer service still need to improve their services in order to maintain their quality brand image and keep the customer loyalty.

\section{References}

Darunanto, D. (n.d.). LAYANAN TERHADAP KEPUASAN PELANGGAN PT . DMS TOUR AND TRAVEL, 201-219.

Hapsari, R., Clemes, M., \& Dean, D. (2016). The Mediating Role of Perceived Value on the Relationship between Service Quality and Customer Satisfaction: Evidence from Indonesian Airline Passengers. Procedia Economics and Finance, 35(October 2015), 388-395. https://doi.org/10.1016/S2212-5671(16)00048-4

Hussain, R., Al Nasser, A., \& Hussain, Y. K. (2015). Service quality and customer satisfaction of a UAE-based airline: An empirical investigation. Journal of Air Transport Management, 42, 167-175. https://doi.org/10.1016/j.jairtraman.2014.10.001

Setiani, B. (2015). Prinsip-Prinsip Pokok Pengelolaan Jasa Transportasi Udara. Jurnal Ilmiah Widya, 1(1). Retrieved from http://ejournal.jurwidyakop3.com/index.php/jurnal-ilmiah/article/view/239

Setyowati, T. M. (2015). Service Quality. Jurnal Manajemen Bisnis Transportasi Dan Logistik, 1-10.

Simarmata, J., \& Keke, Y. (2017). The Influence of Travel Agent , Infrastructure and Accommodation on Tourist Satisfaction, 28(Ictgtd 2016), 281-283.

Surapranata, H., \& Iskandar, B. P. (2013). Evaluation of Customer Satisfaction Using Service Quality Dimension At D' Seuhah Da Lada 
Restaurant, 2(1), 14-28.

Tinggi, S., Transportasi, M., Prasetya, O., Tinggi, S., \& Transportasi, M. (n.d.). LOYALITAS PELANGGAN PADA PERUSAHAAN FREIGHT FORWARDING CUSTOMER LOYALTY OF FREIGHT FORWARDING, 3(3), 299-308.

Warnock-Smith, D., \& Morrell, P. (2008). Air transport liberalisation and traffic growth in tourism-dependent economies: A case-history of some US-Caribbean markets. Journal of Air Transport Management, 14(2), 82-91. https://doi.org/10.1016/j.jairtraman.2008.02.001 